\title{
Re: Perceptions of Plagiarism Among Medical and Nursing Students in Erbil, Iraq
}

$$
\text { رد: تصوّرات الانتحال بين طلاب الطب والتمريض في أربيل، العراق }
$$

Dear Editor,

We read with great interest the recent study by Ismail published in the May 2018 issue of SQUMJ. ${ }^{1}$ In this study, the author concluded that "there is an urgent need to increase students' understanding of plagiarism and its consequences so as to reduce the incidence of this type of academic misconduct". We agree that further education would be a good preventative action to deter unethical publications. However, an interesting question is whether unethical publication problems are due to a lack of knowledge or arise from other factors. ${ }^{2}$

Many cases of plagiarism as well as other unethical publication practices involve senior professors or scientists. ${ }^{3}$ Undoubted, such individuals should already be knowledgeable regarding plagiarism by this point in their careers. When plagiarism is detected, the individual responsible often claims that they were unaware of the infraction, but whether this response is believable should be judged based on evidence. ${ }^{3}$ Nevertheless, we agree with Ismail that further education regarding acceptable publication practices and ethics is a necessity for medical and nursing students. ${ }^{1}$

\section{"Sora Yasri ${ }^{1}$ and Viroj Wiwanitkit ${ }^{2}$}

${ }^{1}$ Department of Primary Care, KMT Primary Care Center, Bangkok, Thailand; ${ }^{2}$ Department of Community Medicine, Dr. D.Y. Patil University, Pune, Maharashtra, India

"Corresponding Author's e-mail: sorayasri@outlook.co.th

\section{References}

1. Ismail KH. Perceptions of plagiarism among medical and nursing students in Erbil, Iraq. Sultan Qaboos Univ Med J 2018; 18:e196-201. doi: 10.18295/squmj.2018.18.02.012.

2. Wiwanitkit V. Letter on the article: Plagiarism in medical schools, and its prevention. Presse Med 2012; 41:887-8. doi: 10.1016/j.lpm. 2012.07.006.

3. Wiwanitkit S, Wiwanitkit V. Responses of authors accused of plagiarism by journal editors. Sci Eng Ethics 2017; 23:309-11. doi: 10.1007/ s11948-016-9752-7. 